\title{
Expanding carceral geographies: challenging mass incarceration and creating a "community orientation" towards juvenile delinquency
}

\author{
E. Brown \\ Department of Criminal Justice Studies, San Francisco State University, 1600 Holloway (HSS 210), \\ San Francisco, CA 94132, USA
}

Correspondence to: E. Brown (eabrown@sfsu.edu)

Received: 25 March 2014 - Revised: 25 July 2014 - Accepted: 28 July 2014 - Published: 22 December 2014

\begin{abstract}
Increasingly, governments are adopting alternative strategies to mass incarceration and drawing on the rhetoric of community to create softer and less restrictive sanctions. This paper argues that this transition provides an opportunity for geographers concerned with incarceration to consider a more expansive understanding of the carceral state. To call for a more geographically expansive consideration of incarceration, this paper draws upon a study of one juvenile court that sought to end racialized over-incarceration by promoting a "community orientation". As a consequence, juvenile detention now acts as a single node in a broader process of sorting, placing, and punishing, but the carceral aspects of juvenile court involvement did not lessen. Instead, the community orientation encapsulated a range of practices that are traditionally outside the state, yet extended the power of the state over a broad geography that resulted in the coerced mobility of children and subjection to greater insecurity. By tracing how the carceral apparatus extends into neighborhoods, community programs, probation practices, and residential placement, I argue that paying more attention to variegated carceral practices is necessary to more fully consider how incarceration has permeated places outside the prison.
\end{abstract}

\section{Introduction}

Geographic attention to mass incarceration has often highlighted the austere and isolating logics of punishment that have pushed millions of people into places far away from their homes that resemble little more than Goffman's (1961) totalizing institutions. Carceral geographers have done much to improve our knowledge about how the incarceration experience shapes modern geographies. Geographers of rural prison buildings, immigrant detention, and the austere spaces of imprisonment have noted the ways that issues of race and class permeate incarceration expansion and resistance (Bonds, 2009; Gilmore, 2007; Martin and Mitchelson, 2009). Geographers concerned with the imprisonment experience have shown how movement, familial social relations, and peer relationships, to name a few, are impacted by imprisonment (Dolovich, 2012; Moran et al., 2012; Turner, 2013). Finally, geographers have critically noted how the modalities of government and redistribution are impacted by the census counting of prisoners, by funding relations between local and state actors, and by the constraints of capitalism and the free market (Hamsher, 2005; Gilmore, 1999; Peck and Theodore, 2008; Theodore et al., 2006). The institutional sites of the prison and immigrant detention have figured prominently in accounts of carceral geographies, especially as these institutional sites are productive of "carceralization", in which "the prison system can be understood as one of the epicentral institutions of these neoliberalized times" (Peck, 2003:226).

Carceral spaces are not limited to the prison and immigrant detention, though, and, as geographers have noted, the practice of incarceration does not end at the boundaries of the prison (Gilmore, 2007; Moran, 2013; Turner, 2013). In addition, the threat of imprisonment, deportation, and other coercive state practices are institutionalized throughout a range of state-centered social-control practices, which take place both in the prison but also through seemingly unrelated practices like state-funded housing (Coutin, 2010; Wacquant, 2008). Parole, probation, and violations of court order all carry the 
threat of incarceration, and the entirety of criminal justice practices take place under the threat of imminent violence (Cover, 1986). Civil court practices, such as gang injunctions, domestic violence restraining orders, and "stay-away" orders all carry the threat of arrest, detention, and imprisonment (Caldwell, 2009). Community-based programs, such as therapy, behavioral classes, and substance-abuse treatment, are frequently court mandated, and non-compliance also results in social-control sanctions (McKim, 2008). Private and publicly funded residential placements often resemble imprisonment, especially when they are mandates, coerced, and take place in settings called "level 14 group homes" in which secure confinement mechanisms rival the most technologically equipped prisons and detention centers (Cox, 2011). Practices of surveillance, banishments, and NIMBYisms are all part of the carceral project, even if their research settings are far removed (or not so far in many cases) from the prison (Beckett and Herbert, 2010; Hubbard, 2004, 2005; Tempalski et al., 2007; Walby, 2005). For many, incarceration does not end at the prison, but rather follows them "into the community" and through life (Travis, 2002).

As of yet, geographers have paid little attention to the practices of state punishment outside of prison, but these practices are an important part of the story of mass incarceration. Frequently cited statistics of incarcerated population neglect the much broader reach of those under some sort of criminal justice supervision; a much higher number than just those incarcerated in prisons and jails (Petersilia, 1997; Mauer, 2006). At the height of US incarceration in 2009, two and a half times the number of people incarcerated were under community supervision; i.e., probation or parole (Glaze and Herberman, 2013). Within recent years, the US has even begun a slight reversal in its unprecedented, continuous rise in incarceration. Currently, rates of incarceration are down, and, for the past 4 years, even on the decline (Glaze and Herberman, 2013). For the first time in almost 40 years, the US did not add to the incarcerated population in 2009. Between 2009 and 2013, the incarceration rate dropped from 1 in 100 people incarcerated to 1 in 108 (which, even at this lower rate, is still exceedingly higher than that in other nations). Courts are also curtailing mass incarceration by reinforcing discretionary power in sentencing for judges, and ordering states to reduce their prison overcrowding (Brown v. Plata, 2011; Burrage vs. US, 2014). California, with the largest imprisoned population in the nation, has been forced into federal receivership for health care and has a federal judge overseeing its prison population declines. Commentators have invoked the "beginning of the end for mass incarceration", hailing the ascendance of a new era in state prison policy of "researchbased alternatives that work better and cost less" (Goode, 2013). While the sheer numbers of those incarcerated still surpass any other nation, and are close to two times the rate of countries that the US considers as peers, after 4 years of incarceration declines, a new trend may be emerging.
This trend, though, may ultimately represent a geographical shift, rather than a shift in the carceral logics of US state power. Certainly, California's realignment is a case study of this very process. In the case of realignment, control is simply shifted from the scale of the state to that of the local community. Instead of serving time in state prison for lower-level crimes, people are now housed in county jails or under intensive probation supervision. ${ }^{1}$ Counties around the nation are now focusing on reentry in order to ease rates of prison readmission, and funding priorities have shifted from prison building to halfway house, treatment centers, alternative courts, and other non-prison-based punishments (California Department of Corrections and Rehabilitation, 2012). Efforts to decrease incarceration are often premised upon a concomitant ascendance of community programs to "address", "help", and "supervise" the formerly incarcerated (Jacobson, 2005).

Below, I draw upon a case study ${ }^{2}$ of one county that sought to decrease incarceration by turning to a community-based model of punishment in its juvenile court system. While the use of incarceration certainly shifted, the result was not a lessening of carceral power. Rather, what was called the "community orientation" often worked to strengthen juvenile court entanglement. Even further, the excesses of carceral power, such as racialized social control and inhumane living conditions, did not disappear. Rather, the reality of the institutional labyrinth of juvenile justice often means community sanctions can resemble even harsh environments like prison (McKim, 2008). Using a case study of one juvenile court's attempt to reduce racialized mass detention, I trace below four ways that carceral geographies extend beyond the doors of juvenile detention and into the neighborhood, community programs, probation practices, and private residential placements. Before I begin, I turn now to theorizing how carceral geographies can understand the role of punishment beyond the apparatuses of confinement, and, in doing so, I call for a more expansive consideration of carceral geographies than currently exists.

\footnotetext{
${ }^{1}$ Though this shift is not without complications. Recently, it was shown that, after a few years of California reducing its incarceration rates, increases have restarted, as counties charge more people with felonies eligible as "second strikes" under the notorious "threestrike" law. If charged with three strikes, the felony is eligible for state prison time. 2013 had more felony second-strike convictions than any year since the law was enacted in 1994 (Thompson, 2014).

${ }^{2}$ This case study is based on over 4 years of research on a single juvenile court, which includes a juvenile court case file review of 150 youths, a review of community files for 100 youths, open ended interviews with 15 youths who left the system, and 2 years of ethnographic research inside Juvenile Hall.
} 


\section{Carceral geography, the prison, and the} community

Allusions to the carceral state almost certainly carry the connotation of a totalizing (and often totalitarian) infused space, akin to Foucault's (1977) conception of prisons as "complete and austere institutions". Often drawing on Goffman's (1961) concept of the prison as a "totalizing space", prison and detention are seen as inaccessible worlds, especially for researchers and places that exist outside the boundaries of everyday life (Martin and Mitchelson, 2009; Belcher and Martin, 2013). Carceral power is often used interchangeably with incarceration complexes, such as prison, immigrant detention, and other forms of confinement (e.g., Dirsuweit, 1999; Wacquant, 2000). Carceral geographies are likewise considered as landscapes of total exclusion, separation, and isolation from the outside world (Moran, 2011, 2013).

Yet, carceral geographers have questioned this totalizing narrative and labeled it as incomplete. Moran (2011) challenges Goffman's claims of prisons as totalizing institutions by discussing how the prison waiting room functions as a "liminal space". Jennifer Turner likewise focuses on the experience of "home" amongst "ex-offenders", noting that, "where might be imagined a sharp boundary between the 'hidden' inside and outside of prisons, there is in fact a myriad of materials that cleave and bind penal geographies that mark the prison wall as a site of transaction and exchange" (2013:485). While, even colloquially, a sharp cleavage exists between the inside and the "outs" (to use the language of the youths with whom I conducted research), increasingly, there is attention being paid to the porosity of prison walls (e.g., Abrams, 2012; Comfort, 2009; Winn, 2010).

Prisons, however, are not the only spaces of confinement. Increasingly, scholars are noting the ways that incarceration is not a practice that is limited to the prison and other spaces of confinement (Cox, 2013). Shabazz (2009), for instance, notes that the practices of punishment and carceral confinement were transferred to the Robert Taylor Homes housing project in Chicago through the use of logics of containment, isolation, and carceral architecture. In the case of the increasingly restrictive immigration policy,, Coutin (2010:200) notes that the increased securitization of immigration makes national spaces akin, in certain respects, to detention centers. This carceral quality is a dimension of national territory, in that undocumented and temporarily authorized migrants cannot exit their countries of residence without losing territorially conferred rights. If they are deported, their countries of origin become extensions of the detention centers that they occupied before exit.

Foucault (2009:16) himself noted that "alternatives" to prison often had the effect of spreading incarceration throughout society, writing that, when liberating the delinquent from the "strict, total and exhaustive incarceration... in the 19th century prisons... something else is unshackled at the same time as the prisoner, something that exceeds him (sic): one liberates the carceral functions".

Carceral spaces cannot be contained by prison doors, and, instead, in many instances, they are much more numerous, insidious, and may be, in some cases, more totalizing than traditional practices of incarceration (Beckett and Harris, 2011; Hackett, 2013; Kilgore, 2013; Lucken, 2013; McKim, 2008; Razac, 2013). While often seen as alternatives to incarceration and carceral power, increasing mechanisms, such as drug treatment, probation, and parole, halfway houses, and diversion programs are used to extend control over the imprisoned long after official prison sentences end (McKim, 2008). Gelsthorpe (2010:380) draws attention to the lived experience of imprisonment, noting that "'welfare' can be experienced as punishment, and indeed, punishment (epitomized by prison) perceived as 'a mother who provides and protects' or as 'a matrix of spiritual rebirth' or as a 'refuge from the prosaic". The indeterminacy of the imprisonment experience suggests that the boundaries of incarceration extend far beyond the prison doors.

Incarceration is not just contained within the imprisonment experience, but rather it is the coercive context of a range of practices that all use the threat and actual imprisonment (no matter how brief) to control, contain, and shape state-subject relations. Practices of policing and surveillance, the establishment of various special enforcement districts, and the utilization of space as a governing tactic through stay-away orders, injunctions, and specialized "no" zones are just some of the ways that geographers have charted to show how exclusion and social control shape the city (e.g., Beckett and Herbert, 2010; England, 2008; Fyfe, 1991; Hubbard and Sanders, 2003; Sanchez, 2004). Likewise, by studying parole, probation, community programs, and "alternatives" to incarceration, punishment and society scholars have noted that a range of state practices supports the institutional process of incarceration. Beckett and Murakawa (2012:222) argue that penal power is "more legally hybrid and institutionally variegated than is sometimes recognized". Calling less visible penal developments the "shadow carceral state", Beckett and Murakawa further note that civil, administrative, and criminal authority are often blended, and non-penal institutions often impose punishments that "compound the heightened surveillance that comes with institutional enmeshment, longer (if not technically 'criminal') rap sheets, and inescapable debt”. Allspach (2010:707) labels these practices the "transcarceral spaces" of prisoners, where both state and non-state actors are "entangled..into the ever widening network of (neo)liberal penal social control". Instead of separated, practices of welfare, education, substance abuse, fines, and other alternatives to punishment are part of the larger geography of carceral power, and can "reactivate more than [they] exceed the old carceral paradigm" (Razac, 2013:389).

Below, I attend to four "transcarceral practices" that labor in the shadow carceral state to demonstrate how the line 
between incarceration and "freedom" is often much more complex in practice. Neighborhood social control, probation practices, mandated community program participation, and residential placement work to encapsulate youths into a broader practice of social control. By drawing on both the practices of juvenile court personnel and the experiences of court-involved youths, I show that, oftentimes, what is perceived as caring and comforting is anything but that. In doing so, I add to Beckett and Murakawa's call for an "institutionally capacious approach to the study of punishment" in calling for a geographically expansive approach to the study of incarceration.

\section{Punishment in the community: social control within and beyond the state}

In the 1990s, an urban county in California found itself with one of the highest rates of incarceration in its juvenile detention center, and with one of the largest "disproportionate minority confinements" in the state. ${ }^{3}$ For many years, it appeared that changing the juvenile justice system would do little, as the logics of social control took hold and incarceration rates rose (though nowhere as rapidly as those in the adult system) into the early 2000s. But, in 2002, the county made a second push for ending racialized mass incarceration in its juvenile system, and turned to what was termed a community orientation to juvenile crime. As an orientation, the community aspect was seen as antithetical to that of the probation orientation that led to the system of mass incarceration in the first place.

The community orientation was the result of concerted efforts by local community activists to swing the pendulum away from practices of social control and towards practices of social welfare and rehabilitation. Years of efforts by local community organizations resulted in substantial changes in the juvenile court system, premised on primarily two different ideas. First, the new community orientation of the juvenile court meant that youths would be adjudicated to the "least-restrictive options" available "in the community". Juvenile probation also set aside a portion of the budget to fund community organizations to provide these least-restrictive options, which included services such as case management, "home detention" supervision, and family counseling and intervention. Second, the court made a commitment to use the most restrictive option last: incarceration in the state juvenile prison system. These two commitments resulted in significant reductions in the juvenile detention population, which led from Juvenile Hall as an overcrowded institution to one that was under-utilized and to just four youths being sent to the state juvenile prison system in 3 years (a remarkable feat for an urban county with one of the highest rates of commitment in the state).

\footnotetext{
${ }^{3}$ Citations withheld to protect anonymity - citations regarding the specific juvenile court under study on file with the author.
}

These decreases in juvenile detention and prison commitments are most certainly laudable, but they did not necessarily manage to extricate the social-control apparatus from the lives of court-involved youths. Rather, the changes actually resulted in failing to meet one of the goals of the community orientation: decreasing the over-incarceration of youths of color. Instead, the new orientation, as I discuss below, resulted in increasing the concentration of youths of color, while diverting mostly white and Asian youths from the system. Scholars of racial disproportionality in the juvenile court rightly note that this is often the result of a "two-track approach to juvenile crime"; that is, social welfare for youths perceived as susceptible to peer influence in their criminality, and social control for youths perceived as leaders and architects of crime (Brown, 2009; Engen et al., 2002; Sampson and Laub, 1993). Generally, white youths are interpreted as committing crime for environmental reasons, and black youths for intrinsic, individual purposes (Bridges and Steen, 1998; Steen et al., 2005). While this may certainly happen in the community-oriented juvenile court that I studied, it is impossible to tell, since, once youths reach juvenile probation and extended court appearances (which consisted of the entirety of the population that I researched), the lowerlevel community-based mechanisms had already whittled the population down to almost entirely youths of color.

Accordingly, the community orientation, as adopted by Juvenile Probation, often does little to address the material circumstances of youths' lives and, instead, is often cited by youths as a considerable deterrent to their exiting the juvenile justice system. As I discuss below, this happens not because of the recalcitrance of court-involved youths, but because the community-oriented reforms instantiate a much broader, more intrusive, and ultimately, for some youths, more incarcerating set of practices than traditional mechanisms of confinement. The carceral geography of the community orientation is, for some youths, actually a deterrent to their attempts to "just survive". Below, I show how four aspects of the community orientation - the focus on criminogenic neighborhoods, mandated community program attendance, extensive probation conditions on home detention, and residential placements - all work to extend, rather than contract, carceral power. The fact that this works through the geographical targeting and shuffling of court-involved youths suggests that, even in the absence of mass confinement, carceral geographies would continue to persist.

\subsection{The carceral neighborhood}

Mass incarceration operates at a number of scales, but, increasingly, the neighborhood is noted as a significant site in shaping the carceral experience (or lack thereof). Scholars have noted that practices of hyper surveillance and incarceration are unevenly experienced across urban areas, and that, often, the majority of prisoners are pulled from just a few neighborhoods (Fagan et al., 2003; Rios, 2011; 
Roberts, 1999; Vera Sanchez and Adams, 2011). Incarceration also has effects at the neighborhood level often called the "collateral consequences of mass incarceration". Voter rolls, elections, political power, government allocations, economic livelihoods, inadequate adult supervision, decreased standards of living, greater poverty, and a host of other conditions are just some neighborhood level collateral consequences (Alexander, 2012; Lipsitz, 2012; Mauer and Chesney-Lind, 2002; Roberts, 2004; Travis, 2002). The impact of prison buildup on the neighborhood is far reaching, and the practices of hyper-policing results in vastly different realities of police enforcement in different locales (Herbert, 1997).

Hyper policing is often the result of concentrating law enforcement officers in high-crime neighborhoods or "hot spots" (Braga, 2001). These very same neighborhoods are also the ones that tend to have the most grievances with police (Rios, 2011; Herbert, 1997). As Herbert (1997) showed in the case of Los Angeles, what this means in practice is that a host of law enforcement officers approach "anti-police" urban neighborhoods with heightened concern for their own safety, and thus are often quick to use coercive force. Youths growing up in "high-crime" neighborhoods are thus subjected to a range of carceral practices, even before they are officially "in the system" (Brunson and Weitzer, 2009; Ocen, 2012; Rios, 2011). Often, seeing adults harassed, arrested, and even shot by police officers are common occurrences and experiences for many court-involved youths.

I talked with several youths in juvenile detention that recalled that some of their earliest memories were often violent interactions between the police and their family. To some extent, the community orientation seeks to end these types of encounters, often by diverting youths from the care of police to the juvenile probation department. As a consequence of a memorandum of understanding between several community organizations and the police department, an internal policy was developed that required police to take youths only to a specially designated youth police station, and, if booking was required, to book them directly into juvenile detention. Lower-level offenses were diverted to a community organization. Even with these diversion practices, though, the rate of arrest in neighborhoods of color far exceeded rates of arrest of youths in other areas of the city. As such, system-involved youths are predominantly from just a handful of neighborhoods.

In 2012, only two neighborhoods had youths with doubledigit concentrations in Juvenile Hall; one neighborhood had $25 \%$ of detainees and is, today, the site of the largest concentrations of African Americans in the city; another had almost $20 \%$ detainees and is the neighborhood concentration of Latinos. These neighborhoods had two-to-three times the rate of the next greatest concentration ( $8 \%$ ), and many times the rates of neighborhoods with the lowest rate of detainees (some had only a quarter of a percent). The fact that neighborhoods have disparate crime rates is nothing new, and has been noted since the Chicago School in the early 20th century. Yet, this continuity plays an important role in how carceral geographies shape the city, since growing up in some places constitutes a greater risk for criminal justice surveillance than life in other neighborhoods.

This geography of crime is reiterated yearly in Juvenile Probation Department annual reports, which produces maps of Juvenile Hall admissions by zip code and by political district boundaries. These maps show a definitive concentration in the number of referrals, but that concentration increases dramatically when just detainees in Juvenile Hall are counted. Accordingly, almost $85 \%$ of Juvenile Hall detainees are black or Latino, even as the number of admissions to Juvenile Hall has decreased by almost $40 \%$ since the plan went into place. For young women, the racial concentration is even more severe, as over $90 \%$ of detainees are black or Latino. Juvenile Hall, and eventual adult incarceration, was, for many of the youths with whom I spoke, a normalized experience, and several youths knew each other from the neighborhood. It was often comical how Juvenile Hall served as just another extension of the confined spaces of childhood as young people tried to pass notes, often to those of the opposite sex, through the spaces of Juvenile Hall. The carceral neighborhood, however, is not just a chronicle of police practices, but also shapes the spaces of growing up for many youths of color.

Feeling under threat and "under siege" (Collins and Kearns, 2001) by police and probation officers was a common sentiment when youths in Juvenile Hall were asked about experiences of incarceration. These feelings were poignantly displayed in general discussions of police, crime, and the neighborhood, but also motivated a group of youths and custodial staff to approach me with questions about how gang injunctions were promulgated. Though gang injunctions were directed only at adults, many of the youths had heard of them from police. Indeed, several youths noted that police used the threat of appearing on the gang injunction in order to informally accomplish their aims, such as moving youngsters off the street, and as a strategy to find out information from youths. These experiences revealed that the neighborhood, as a space of confinement, was one that was palpable for several youths.

This section culminated with cognitive maps of their neighborhoods, and Donald was one youth drew a map that seemed to resonate with many his classmates. Donald's map was of the neighborhood that had the highest representation in Juvenile Hall. Donald described his map with rich imagery of the neighborhood, one that is far from the criminogenic representation given by mapping arrest rates. Donald's map shows the neighborhood as a carceral space, where police surveillance is omnipresent. Several spots in the neighborhood - for example, in abandoned buildings - served as central meeting points for the youths in the neighborhood, and provided a place in which they could congregate without being stopped by the police. Routes around the neighborhood were also important, as police generally concentrated on just 
two different streets that could be avoided if youths walked through vacant lots and private property.

Carceral spaces are not just places that social-control tactics target, but they are also places in which the austerity of the life - often symbolized by the "camp" or "bare life" - is often on display. Reginald worked with a local community organization on a playwriting project where students were taught to create a one-act play, with two animal characters, using metaphor to describe an issue that they were confronting. Reginald described his neighborhood - the same one as Donald's - as similar to a "lion pit". Reginald's play told of a young lion trying to make it out of the lion pit, but continuously confronted with seemingly insurmountable obstacles from the outside that continuously pushed him back into the lion pit. His closing scene described desperately trying to climb out of the lion pit, hanging on by his nails, as he descended into the forces of the violent, fiery pit. To conclude, the lion asks his girlfriend to remember him and the love they shared. Reginald was facing a long adult sentence, and succumbing to the lion pit meant a lifetime of incarceration ahead of him. For Reginald, the carceral context of the neighborhood was inseparable from the carceral context he faced. While he would surely not have conflated his neighborhood in its entirety with the carceral surveillance that was omnipresent, this certainly was a palpable aspect of neighborhood life for him. Even further, being thrown into the lion pit surely represented how, even in the absence of formal camp/prison/detention boundaries and walls, the biopolitical practices of "othering" still take place apace (Stenson, 2005).

Neighborhood practices of incarceration then extend carceral power beyond the institutions of prison and detention. Police surveillance, targeting of neighborhood crime spots, and frequent familial interactions with police all represent ways that carceral power operates in a more fluid, dynamic, and, ultimately, more expansive geographical form. Geographically oriented crime control polices, like hot-spot policing, broken windows, and even community policing, are simultaneously ways that carceral power extends unevenly across urban space, recreating geographies of inequality and exclusion through the micropolitics of neighborhood crime control (Brown, 2010). Even further, the mythology of highcrime neighborhoods is often the basis that residents of other neighborhoods use to pathologize urban neighborhoods of color and justify disproportionate policing and prison policies (Krysan, 2002; Sampson, 2012). Urban processes of social control, then, are part of the condition of mass incarceration, and help foreground incarceration as part of the life course for neighborhood residents (Pettit and Western, 2004).

\subsection{The carceral community}

Neighborhood oriented practices of social control, however, are not the only ways in which carceral power is practiced over more expansive geographies than the prison or the camp. As discussed earlier, efforts to reduce practices of incarceration, such as neighborhood crime control policies, are often premised on the assumption that the use of community-based programs is ultimately kinder, more caring, and, for the purposes of institutional legitimacy, more rehabilitative. Certainly, evidence for this position is abundant and, often, community-based programs provide a forum for people to escape criminality, lessen some of the binds of incarceration, and often link people with key mechanisms of support in their lives. And, in many cases, this happened with the youths who I interviewed, as well. Several youths reported that community organizations often introduced them to a key individual who had an incredible impact on their lives, often providing support long after they left the juvenile court system (and thus long after the organization received payment to provide services). This practice also seemed to extend to a wide range of organizations, from the local, grassroots racial-justice-oriented groups to national nonprofit service providers. These experiences, though, were generally limited to a particular individual, or a small group of individuals (especially in the case of the local grassroots nonprofits), and did not encapsulate the entirety of practices that the community-oriented reforms, discussed above, instantiated.

Rather, the community orientation resulted in a host of organizations that played a critical role in the delivery of social services in juvenile justice. Mechanisms traditionally seen as integral to the social welfare push in juvenile justice, such as case management, placement, and therapy, were devolved to the community scale (Armstrong, 2002). One report on the new orientation in probation reported 30 different organizations providing some sort of service to court-involved youths. The top five services provided were case management, tutoring/help with homework, mentoring, job readiness/employment training, and extra-curricular/after-school activities. While these services do not necessarily extend the carceral state, these services are used as part of probation supervision, and thus the court mandated attendance. Youths were often sorted into community programs based on three characteristics: perceived race, neighborhood residence, and criminal charges. Of the 30 organizations, one-third targeted Latinos and African Americans and one-third targeted the two neighborhoods with highest crime rates. Almost every single court order of probation in over 150 reviews of files ordered court youths to attend at least one of these community programs. Often, just race and neighborhood residence would result in a youth being ordered to attend a community organization, which could result in youths attending groups that often had little to do with their actual situation.

In all, 3 youths reviewed out of 50 young men's case files, for instance, were court-ordered to participate in a program about guns for young black men. Yet, only one of the cases actually had anything to do with guns, and that young man did not use the firearm in the commission of a crime, but was rather caught with a loaded firearm on a school campus. The two other youths did not have gun charges; one was referred 
to the court for sexual assault and the other was referred for drugs. Another young women recalled having to attend a group about self-empowerment for young women of color, but recounted that this entailed her having to cross the city, take time away from caring for her family, and did little to change the circumstances of her life. Another young woman reported being placed in a neighborhood-based substanceabuse group, even though her charge was for theft.

The most common complaint about community organizations then stemmed neither from the content nor from the character or people within the organizations, but rather from the often-forced geographies of mobility upon which youths were forced to embark as a condition of successful probation (Moran et al., 2012). Frequently, youths would be ordered to a long list of community conditions, including participation in local neighborhood groups (boys and girls club was one of the most common), after-school tutoring, before school truancy prevention programs, substance-abuse counseling, job readiness programs, and other mechanisms. As an example, a young man with typical probation conditions was ordered to attend individual counseling and family counseling in one neighborhood, job training in another, and school in yet a third neighborhood. Traveling to probation appointments meant yet another neighborhood.

In a discussion with one group of youths, the coerced geographical mobility that they confronted actually resulted in obstacles to their successful school attendance and exiting probation. One reason for this is that many youths did not feel that they could navigate the city in direct routes; rather, several youths recounted how it was common to avoid sections of the city that housed their enemies. This often meant that traveling to a community organization in a neighborhood other than one's own could take up to 2 hours. Even further, the youths indicated that the 2 hours were fraught with concern for one's safety, as leaving the neighborhood meant "you never knew what was going to happen to you". Reports of a friend being shot at rival bus stops further fueled fear of traveling through many parts of the city to attend the range of community organization meetings. Ultimately, mandating community organization attendance created geographies of social control that exposed some youths to further insecurity, and, prompted as a resistance strategy, non-compliance. Noncompliance, however, often resulted in further social-control sanctions, and could even extend the probationary supervision period. Most would argue that community organizations are entities squarely outside the state, but, for the youths with whom I spoke, they were integral to the overall incarceration experience.

\subsection{Probation as carceral practice}

Perhaps part of the issue with community organizations that fulfill the logics of often state-centered carceral power is that, ultimately, participation is mandated and overseen by probation officers, and it is widely used, often to little effect. Ad- ditionally, although probation and parole officers are often seen as agents of social welfare in the legal system, the job is oftentimes oriented towards social control (Lynch, 1998; Simon, 1993). Probation is widely used in the court, and represents one of the "least-restrictive" alternatives to traditional mechanisms of incarceration. Probation is used both before and after adjudication. Youths who are booked into Juvenile Hall are often released on home detention pending trial. Younger youths with minor crimes are often eligible for "voluntary probation", where the case may be dismissed by probation officer discretion, with little oversight of the youths. Youths whose crimes are infrequent, not felonies, and who are over 14 are eligible for informal probation. Finally, other youths are eligible for wardship probation, where the probation conditions are much more intrusive and demand weekly or biweekly meetings between youths and their assigned probation officer.

Whether or not probation was an institutional quagmire is certainly debatable, but, for many of the youths, probation practices instituted a whole host of social-control practices in addition to the practices of social welfare practiced by community organizations above. Like community programs, probation conditions often forced youths to travel across multiple areas of the city, subjecting them to increase insecurity, greater demands on their time, and a litany of conditions to satisfy. In addition to community program attendance, youths also had to attend weekly meetings with their probation officers, get drug tested, wear ankle monitors, attend school daily, and obey a curfew (commonly set at 5 or 6 p.m.). Compliance meant not only attending meetings, but also doing so within a limited number of hours. Frequently, this meant that youths were up early to attend court-ordered study sessions at 7 a.m., attended school by 8 a.m., and only had from between 2 and 6 p.m. to comply with probation conditions. Exceptions to curfew conditions could be made if the demands of probation conflicted with the curfew time, but this happened infrequently. Geographic mobility was also limited, as most youths had stay-away orders from parts of the city as part of their probation conditions. For the youths, the city itself represented a parcel of places to which one could and could not go, dotted throughout by social-control agencies with whom one was mandated to meet.

Part of what made probation "so hard to get off if you're on it" was the litany of conditions. One young woman wrote that the reason she felt trapped was that "it makes it hard to focus on myself when somebody else is focused on me and wants to run me". This quote illustrates the way in which probation, as a practice that is an alternative to incarceration, still acts as a carceral presence in the lives of the youths. Others named the "so many conditions" that one had to meet to be released from probation, and that these conditions were meant to "keep you here and give you a challenge that takes ten times more strength to get back on top".

Probation, though premised as a least-restrictive alternative, was seen by some youths as a "trap" that helped instan- 
tiate the cycle of incarceration, rather than arresting it. Some youths called out early run-ins with police, where the mechanisms of voluntary and informal probation did little to help them with their struggles for survival. At the end of one particularly heartfelt discussion of probation, a young woman noted that she had been in and out of Juvenile Hall multiple times, on probation since she was a young teen, and, as she was nearing her 18th birthday, she was just hoping that her probation officer would finally recognize that what she needed help with was "survival", which she defined as just "like a new pair of shoes or money to buy some food". Despite her plea, the institution of probation is not set up to provide these amenities, as youths are primarily given assistance through traditional therapy, counseling, or group-based activities.

Ultimately, however, there was a sense of resolution about probation conditions, and the need for compliance, even if it interfered with one's own sense of morality. This ethos of personal responsibility was palpable in the discussion of probation with both young men and women. Both talked about the need to stay the probation course, without messing up. Frequently, though, these were youths who had been on probation several times, so these discussions were also laden with melancholic feelings of regret. Several noted that they had messed up earlier in life by not taking advantage of what probation did have to offer. One young woman lamented that "it should not take for [her] to get on probation to shape up. It shouldn't have taken this many chances to open [her] eyes. [She] expect[s] more of [her]self"'. These feelings of regret and entrapment reflected the strength of carceral power over the lives of the youths. Not only did probation conditions force youths to traverse the city as an object of social-control practices, but it also impacted the youths' very subjectivity. Indeed, the most "successful" youths to make it out of juvenile probation did so by assuming the mantra of personal responsibility, or, as one young woman put it, change happens "when you finally believe you're a failure".

Perhaps this sense of failure was reinforced by one of the most interesting probation conditions to which youths were assigned: attendance at a probation-run high school. Several youths were ordered to attend this high school, but the vast majority of students who talked about it viewed it negatively. When probed on this negative viewpoint, one youth noted that he felt as if the school's primary purpose was to punish him, rather than to help him. Another youth said that "it's not school; it's jail". While many students did not have positive connotations of public high school, the probation-run school was widely viewed as negative. The school not only did probation checks daily on the students, but students were drugtested on campus, as well. Often, this meant that others that had committed crimes, even co-minors in the same cases, attended school together. The school is also isolated from other youths, thereby geographically marking the youths as different and exceptional from other youths. Congregating youths in the same geographical space, all on probation, resembles sharply the types of industrial residential schools that were little more than juvenile prisons (Platt, [1969] 1977). While the youths can leave after school (often to attend to their probation conditions), the probation school places the carceral complex squarely in the heart of the city, and as just one node among many in the coerced mobility of the probation carceral complex.

\subsection{Carceral archipelagos beyond the state}

Decreasing incarceration did not necessarily mean relenting control over the lives of youths just to the mechanisms of probation. Rather, many youths were "BPC", to use the lingo of the court, or "beyond parental control", and thus could not be left to complete probation in the community. Rather, as a condition of probation, some youths were often sent to an "out-of-home placement", or an OOHP. In practice, an OOHP could mean two things: a placement with a relative who had been approved by the court, or a placement with a private residential placement facility. While these are often seen as outside the network of carceral power, residential placements and OOHPs with a relative actually worked to extend this type of power over the home spaces of youths.

For youths, the difference between institutional placement and being released into the community was oftentimes simply the availability of a home approved by the court. When youths were declared beyond parental control, oftentimes, it did not necessarily mean that the individual youth was at fault, but rather that neglect, abuse, or dysfunctional relationships meant that the youths would be better (according to the court) in another environment. Some youths had key figures that tried to step in to offer shelter outside the juvenile system. For guardians that attempted to do this, though, homes first had to be approved by the probation officer. For these types of out-of-home placements, probation officers interviewed guardians and inspected homes to ensure that they complied with the probation officers' sense of an appropriate home space, which included ensuring that youths had a private bedroom.

Even in cases where adults professed a willingness to give up their own bedrooms to accommodate this rule, the potential that a youth would not have a room would result in the denial of placement. Some families went to great lengths to secure their homes for youth, including home visits and criminal record checks, but other factors led to their inability to play this role. One young woman lamented that her probation officer was "too lazy to do something for [her]" and, when probed, said that the denial of her grandfather to serve as guardian led to her continued placement in group homes. She asked: "Who is he to say my grandpa is too old to take care of me?" For many youths, moving from home to home over the course of their short lives happened all too frequently, and it proved frustrating that, when finally given a chance for a stable home, often with a trusted and loved family member, the court would deny it. 
Youths who could not be placed with extended networks often were sentenced to residential placement in a network of private facilities. These facilities were widely derided by youths in our conversations about probation conditions, and likened to a trap; as well. One young woman indicated that group homes "make you a worse person" and another said that they "give you no hope". Discussions of residential placement were dominated by themes of how the "less restrictive alternative" to juvenile detention was, in actuality, more restrictive than in Juvenile Hall. Several youths professed a preference for Juvenile Hall over group homes, and running from a residential placement to get back into Juvenile Hall was a strategy that youths used frequently. When probed about why they disliked group homes, the geography of residential placement played a key role.

For many, residential placement was seen as a more restrictive punishment than staying in Juvenile Hall because it often meant staying in places far from home and from one's family. While, initially, youths are often placed in homes in the broader metropolitan area, the restrictions on visiting were often more stringent than those at Juvenile Hall (which was more stringent than in county jail, which led a few youths to actually request transfer to the jail upon their 18th birthday). Youths in placements could visit families, but it was often further for them to travel than the centrally located Juvenile Hall, and often not well served by public transportation. Most "local" group homes required at least an hour of travel from the home neighborhoods of youths, and family visits were governed as part of a "treatment" plan. Many youths were denied family visits for the first month of placement, or until they achieved particular behavioral levels, whereas, in Juvenile Hall, family visits are legally mandated and cannot be restricted, except in exceptional circumstances.

Even further, the use of placement illustrated how probation conditions used space explicitly as a governing tactic. One of the most frequently cited problems with placement was the high rate of what is called "placement failure". On average, a sample of 67 young women resulted in a placement failure of two placements per person, which included youths who had never been placed in an OOHP before. Some cases had as many as 11 different placement "failures." According to the juvenile probation department, placement fails in $72 \%$ of cases with black youths and $50 \%$ of cases with Latino youths. The high rate of placement failure meant that the first placement was often in the metropoli$\tan$ area, but, if the youths absconded from placement, future placements would be in more geographically distant locales. For instance, one case that went through eleven different placements before leaving the juvenile justice system went to group homes that were successively further and further away, until finally being placed 3000 miles across the country. Each time, space was used to counter the argument that, if the youth was placed locally, it was, in the words of one probation officer, "a setup for failure".
Youths described this institutional geography as increasingly frustrating. Some said they ran from their placement because of the distance between themselves and their families. Frequently, they were new parents, and a placement meant being away from their children at a critical point in their development. One young man said that, when he was in residential placement, "anger just built up because [he] was away from [his] family". And one young woman succinctly captured just how probation officers used space as a governing tactic, saying that, "when you run, they won't help you, they just send you further." Youths also noted that a residential placement was also more insecure than Juvenile Hall, where they had their own rooms that locked. Additionally, placement "time served" was not the same as Juvenile Hall time served. Juvenile Hall time served counted against the dispositional sentence, whereas stays in placement did not. Placement ended upon successful completion, but, for many youths, this could mean several different facilities before they finally found "success".

For these reasons, many youths actually preferred to stay in Juvenile Hall rather than being placed in a residential facility. A small portion of youths even reported purposely tanking placement interviews and actively refusing to go to a placement in order to serve out their dispositions in Juvenile Hall. Although outside the operation of the state, residential placements still played a critical role in the incarceration experience of urban youths. While it was theorized as a least-restrictive alternative to incarceration, the practice of a residential placement was often more intractable, longer, and more insidious than that of Juvenile Hall.

\section{Conclusions}

Carceral practices certainly extend beyond the sites of prison and detention. In the case study above, juvenile detention is the traditional site of carceral practice, yet is just a single node in larger practices of social control. Practices of carceral power extend into the neighborhood, and are often part of the landscape of growing up for court-involved youths and precede court intervention. Mandated community program attendance further instantiates a coercive geographic mobility that extends the carceral complex over the intricate map of the city forcing youths to travel to multiple locales to receive state-mandated help and care. Explicit social-control practices, like juvenile probation, are also part of the carceral complex and make the city the site of restriction, exclusion, and limitation. Residential placement in private homes is deemed an alternative to incarceration, but these sites can practice more insidious mechanisms of control than traditional sites of confinement. Together, neighborhood, community programs, probation, and residential placements are all examples of institutions unlike prison, yet are also all practices that extend the carceral state across multiple spaces and scales. 
A geographically expansive understanding of the carceral opens up incarceration as a multi-institutional, fluid, and indeterminate practice. Ultimately, carceral geographies must not only understand how prison spaces came to be the institutional exemplar of late 20th century US society, or how they are ultimately porous institutions (Garland, 2001); rather, a fuller understanding of the power of the carceral society must attend to incarceration as, ultimately, a spatial practice defined not just by its most extreme example. Already, even in its nascent stage, carceral geographers are starting to question the notion of the "total institution" (Moran, 2013). As the field of carceral geography moves forward, it must not only contend with the notion of incarceration, as defined in its totality by the prison; it must also consider how the multiplicity of carceral spaces ultimately work together to create the carceral society that is so common to modern day descriptions.

Acknowledgements. I would like to thank two anonymous reviewers for their very helpful and insightful comments on earlier drafts. I would also like to thank Jennifer Turner for her editorial oversight. All mistakes, omissions, and other errors are my responsibility alone.

Edited by: J. Turner

Reviewed by: two anonymous referees

\section{References}

Abrams, L. S.: Envisioning life "on the outs": Exit narratives of incarcerated male youth, Int. J. of Offender Therapy and Comparative Crim., 56, 877-896, 2012.

Alexander, M.: The new Jim Crow: Mass incarceration in the age of colorblindness, The New Press, 2012.

Allspach, A.: Landscapes of (neo-)liberal control: the transcarceral spaces of federally sentenced women in Canada, Gender Place Cult., 17, 705-723, 2010.

Armstrong, S.: Punishing not-for-profit: Implications of nonprofit privatization in juvenile punishment, Punishm. Soc., 4, 345-368, 2002.

Beckett, K. and Harris, A.: On cash and conviction Monetary sanctions as misguided policy, Criminology \& Public Policy, 10, 509537, 2011.

Beckett, K. and Herbert, S.: Banished: the new social control in urban America, Oxford University Press, Oxford, 2010.

Beckett, K. and Murakawa, N.: Mapping the shadow carceral state: Toward an institutionally capacious approach to punishment, Theor. Criminol., 16, 221-244, 2012.

Belcher, O. and Martin, L.: Ethnographies of closed doors: Conceptualising openness and closure in US immigration and military institutions, Area, 45, 403-410, 2013.

Bonds, A.: Discipline and devolution: Constructions of poverty, race, and criminality in the politics of rural prison development, Antipode, 41, 416-438, 2009.

Braga, A. A.: The effects of hot spots policing on crime, Ann. Am. Acad. Polit. SS, 578, 104-125, 2001.
Bridges, G. S. and Steen, S.: Racial disparities in official assessments of juvenile offenders: Attributional stereotypes as mediating mechanisms, Am. Sociol. Rev., 63, 554-570, 1998.

Brown, E.: Crime, Governance and Knowledge Production: The "two track common sense approach" to juvenile criminality in the United States, Social Justice, 35, 102-121, 2009.

Brown, E.: Race, Urban Governance, and Crime Control: Creating Model Cities, Law Soc. Rev., 44, 769-804, 2010.

Brown v. Plata: 563 U.S. Supreme Court, 2011.

Brunson, R. K. and Weitzer, R.: Police relations with black and white youths in different urban neighborhoods, Urban Aff. Rev., 44, 858-885, 2009.

Burrage v. United State: 12-7515 U.S. Supreme Court, 2014.

Caldwell, B.: Criminalizing day-to-day life: A socio-legal critique of gang injunctions, Am. J. Crim. L., 37, 241-290, 2009.

California Department of Corrections and Rehabilitation: Implementation of the Post Release Community Supervision Act of 2011, available at: http://www.cdcr.ca.gov/realignment/docs/ PRCS-County.pdf (last access: 26 November 2013), 2012.

Collins, D. C. A. and Kearns, R. A.: Under curfew and under siege? Legal geographies of young people, Geoforum, 32, 389-403, 2001.

Comfort, M.: Doing time together: Love and family in the shadow of the prison, University of Chicago Press, 2009.

Cover, R. M.: Violence and the Word, Yale Law J., 1601-1629, 1986.

Coutin, S. B.: Confined within: National territories as zones of confinement, Polit. Geogr., 29, 200-208, 2010.

Cox, A.: Doing the programme or doing me? The pains of youth imprisonment, Punishm. Soc. 13, 592-610, 2011.

Cox, A.: New visions of social control? Young people's perceptions of community penalties, J. Youth Stud., 16, 135-150, 2013.

Dirsuweit, T.: Carceral spaces in South Africa: a case study of institutional power, sexuality and transgression in a women's prison, Geoforum, 30, 71-83, 1999.

Dolovich, S.: Two models of the prison: Accidental humanity and hypermasculinity in the L.A. County Jail, J. Crim. Law Crim., 102, 965-1117, 2012.

Engen, R. L., Steen, S., and Bridges, G. S.: Racial disparities in the punishment of youth: A theoretical and empirical assessment of the literature, Soc. Probl., 49, 194-220, 2002.

England, M.: When 'good neighbors' go bad: territorial geographies of neighborhood associations, Environ. Plann. A, 40, 2879-2894, 2008.

Fagan, J., West, V., and Holland, J.: Reciprocal effects of crime and incarceration in New York neighborhoods, Fordham Urban Law Journal, 30, 1551-1602, 2003.

Foucault, M.: Discipline and Punish, Vintage Books, New York, 1977.

Foucault, M.: Alternatives to the Prison Dissemination or Decline of Social Control?, Theor. Cult. Soc., 26, 12-24, 2009.

Fyfe, N. R.: The police, space and society : the geography of policing, Prog. Hum. Geogr., 15, 249-267, 1991.

Garland, D.: The culture of control: crime and social order in contemporary society, University of Chicago Press, Chicago, 2001.

Gelsthorpe, L.: Women, crime and control, Criminology and Criminal Justice, 10, 375-386, 2010. 
Glaze, L. E. and Herberman, E. J.: Correctional Populations in the United States, 2012, Department of Justice, Bureau of Justice Statistics, Washington D.C., NCJ 243936, 2013.

Gilmore, R. W.: Globalisation and U.S. prison growth: from military Keynesianism to post-Keynesian militarism, Race Class, 40, 171-188, 1999.

Gilmore, R. W.: Golden gulag: prisons, surplus, crisis, and opposition in globalizing California, University of California Press, Berkeley, 2007.

Goffman, E.: On the characteristics of total institutions, Symposium on preventive and social psychiatry, 43-84, 1961.

Goode, E.: US Prison Populations Decline, Reflecting New Approach to Crime, New York Times, A11, 2013.

Hackett, C.: Transformative Visions: Governing Through Alternative Practices and Therapeutic Interventions at a Women's Reentry Center, Feminist Criminology, 8, 221-242, 2013.

Hamsher, D.: Counted out Twice: Power, Representation \& the "Usual Residence Rule" in the Enumeration of Prisoners: A State-Based Approach to Correcting Flawed Census Data, J. Crim. Law Crim., 96, 299-328, 2005.

Herbert, S. K.: Policing space: territoriality and the Los Angeles Police Department, University of Minnesota Press, Minneapolis, MN, 1997.

Hubbard, P.: Cleansing the metropolis: Sex work and the politics of zero tolerance, Urban Stud., 41, 1687-1702, 2004.

Hubbard, P.: Accommodating otherness: anti-asylum centre protest and the maintenance of white privilege, T. I. Brit. Geogr., 30, 52-65, 2005.

Hubbard, P. and Sanders, T.: Making space for sex work: Female street prostitution and the production of urban space, Int. J. Urban Regional, 27, 75-89, 2003.

Jacobson, M.: Downsizing prisons: How to reduce crime and end mass incarceration, NYU Press, 2005.

Kilgore, J.: Progress or More of the Same? Electronic Monitoring and Parole in the Age of Mass Incarceration, Critical Criminology, 21, 123-139, 2013.

Krysan, M.: Community Undesirability in Black and White: Examining racial residential preferences through community perceptions, Soc. Probl., 49, 521-543, 2002.

Lipsitz, G.: "In an Avalanche Every Snowflake Pleads Not Guilty": The Collateral Consequences of Mass Incarceration and Impediments to Women's Fair Housing Rights, UCLA Law Review, 59, 1746-1809, 2012.

Lucken, K.: "You Say Regulation, I Say Punishment": The Semantics and Attributes of Punitive Activity, Critical Criminology, 21, 193-210, 2013.

Lynch, M.: Waste Managers? The new penology, crime fighting, and parole agent identity, Law Soc. Rev., 32, 839-869, 1998.

Mauer, M.: Race to incarcerate, revised and updated, New Press, New York, 2006.

Mauer, M. and Chesney-Lind, M.: Invisible punishment: the collateral consequences of mass imprisonment, New Press, New York, 2002.

Martin, L. L. and Mitchelson, M. L.: Geographies of detention and imprisonment: interrogating spatial practices of confinement, discipline, law, and state power, Geography Compass, 3, 459477, 2009.

McKim, A.: "Getting Gut-Level": Punishment, gender and therapeutic governance, Gend. Soc. F., 22, 303-323, 2008.
Moran, D.: Between outside and inside? Prison visiting rooms as liminal carceral space, GeoJournal, 78, 1-13, 2011.

Moran, D.: Leaving behind the "total institution"? Teeth, transcarceral spaces and (re) inscription of the formerly incarcerated body, Gender Place Cult., 21, 1-17, 2013.

Moran, D., Piacentini, L., and Pallot, J.: Disciplined mobility and carceral geography: prisoner transport in Russia, T. I. Brit. Geogr., 37, 446-460, 2012.

Ocen, P. A.: The New Racially Restrictive Covenant: Race, Welfare, and the Policing of Black Women in Subsidized Housing, Ucla Law Rev., 59, 1540-1582, 2012.

Peck, J.: Geography and public policy: mapping the penal state, Prog. Hum. Geogr., 27, 222-232, 2003.

Peck, J. and Theodore, N.: Carceral Chicago: Making the Exoffender Employability Crisis, Int. J. Urban Regional, 32, 251281, 2008.

Petersilia, J.: Probation in the United States, Crime Justice, 149200, 1997.

Pettit, B. and Western, B.: Mass imprisonment and the life course: Race and class inequality in US incarceration, Am. Sociol. Rev., 69, 151-169, 2004.

Platt, A.: The Child Savers: the invention of delinquency, University of Chicago Press, Chicago, IL, [1969] 1977.

Razac, O.: Virtual aspects and materiality in electronic surveillance, Deviance Soc., 37, 389-403, 2013.

Rios, V.: Punished: Policing the Lives of Black and Latino Boys, New York University Press, New York, 2011.

Roberts, D.: The social and moral costs of mass incarceration in African American communities, Stanford Law Rev., 56, 12711306, 2004.

Roberts, D.: Foreword: Race, vagueness and the social meaning of order-maintenance policing, J. Crim. Law Crim., 89, 775-836, 1999.

Sampson, R. J.: Great American City: Chicago and the enduring neighborhood effect, University of Chicago Press, Chicago, 2012.

Sampson, R. J. and Laub, J. H.: Structural Variations In JuvenileCourt Processing - Inequality, The Underclass, And SocialControl, Law Soc. Rev., 27, 285-311, 1993.

Sanchez, L.: The global e-rotic subject, the ban, and the prostitutefree zone: sex work and the theory of differential exclusion, Environ. Plann. D, 22, 861-883, 2004.

Shabazz, R.: “So High You Can't Get Over it, So Low You Can't Get Under it" Carceral Spatiality and Black Masculinities in the United States and South Africa, Souls, 11, 276-294, 2009.

Simon, J.: Poor discipline: parole and the social control of the underclass, 1890-1990, University of Chicago, Chicago, 1993.

Steen, S., Bond, C. E., Bridges, G. S., and Kubrin, C. E.: Explaining assessments of future risk, Our children, their children: Confronting racial and ethnic differences in American juvenile justice, edited by: Hawkins, D. F. and Kempf-Leonard, K., University of Chicago Press, 245-269, 2005.

Stenson, K.: Sovereignty, biopolitics and the local government of crime in Britain, Theor. Criminol., 9, 265-287, 2005.

Tempalski, B., Friedman, R., Keem, M., Cooper, H., and Friedman, S. R.: NIMBY localism and national inequitable exclusion alliances: The case of syringe exchange programs in the United States, Geoforum, 38, 1250-1263, 2007. 
Theodore, N., Martin, N., and Hollon, R.: Securing the city: Emerging markets in the private provision of security services in Chicago, Social Justice, 85-100, 2006.

Thompson, D.: California Plan to Ease Overcrowding Undermined by Counties, Contra Costa Times, available at: http://www.contracostatimes.com/news/ci_25311083/ california-plan-ease-prison-crowding-undermined-by-counties (last access: 12 March 2014), 10 March 2014.

Travis, J.: Invisible punishments: An instrument of social exclusion, in: Invisible punishment: The collateral consequence of mass imprisonment, edited by: Mauer, M. and Chesney-Lind, M., New Press, New York, 15-36, 2002.

Turner, J.: Re-"homing" the ex-offender: constructing a "prisoner dyspora", Area, 45, 485-492, 2013.
Vera Sanchez, C. G. and Adams, E. B.: Sacrificed on the Altar of Public Safety: The Policing of Latino and African American Youth, Journal of Contemporary Criminal Justice, 27, 322-341, 2011.

Wacquant, L.: The new "peculiar institution": On the prison as surrogate ghetto, Theor. Criminol., 4, 377-389, 2000.

Wacquant, L.: Urban outcasts: a comparative sociology of advanced marginality, Polity, Cambridge, MA, 2008.

Walby, K.: How closed-circuit television surveillance organizes the social: An institutional ethnography, Can. J. Sociol., 30, 189$214,2005$.

Winn, M. T.: "Betwixt and between": literacy, liminality, and the celling of Black girls, Race Ethnicity and Education, 13, 425447, 2010. 